\title{
A fuzzy application on MICE hosting: An Iranian case study for locating suitable areas based on P.L Indexes
}

\author{
Nazanin Tabrizi*, Massoud Taghvaei and Hamid Reza Varesi
}

Department of Geography and Urban Planning, Faculty of Geographic Science and Planning, University of Isfahan, Isfahan, Iran

\begin{tabular}{|c|c|}
\hline A R T I C L E I N F O & A B S T R A C T \\
\hline $\begin{array}{l}\text { Article history: } \\
\text { Received July 5, } 2011 \\
\text { Received in Revised form } \\
\text { October, 12, } 2011 \\
\text { Accepted 18 December } 2011 \\
\text { Available online } \\
30 \text { December } 2011 \\
\text { Keywords: } \\
\text { MICE tourism } \\
\text { Physical and location related } \\
\text { (P.L) indexes } \\
\text { Fuzzy Logic }\end{array}$ & $\begin{array}{l}\text { Today, countries compete to gain political, economic, social and cultural advantages. In } \\
\text { addition, cities are trying to demonstrate their predominance on local and regional levels and } \\
\text { achieve development by using managerial science. Meetings, incentives, conventions and } \\
\text { exhibitions tourism (MICE) hosting as a significant element of urban tourism is one of the } \\
\text { effective methods to obtain urban development around the world. However, no specialized } \\
\text { planning and independent investments in regard to these activities have been organized in Iran. } \\
\text { Aiming to identify suitable areas in the northern part of Iran, the present research intends to } \\
\text { recognize the necessary physical and location related (P.L) indexes to perform the specialized } \\
\text { activities of MICE tourism in this region. So at first, indispensable indicators to accept special } \\
\text { role of MICE tourism are identified and then using GIS and fuzzy method, adapted areas are } \\
\text { assigned. The result map shows that a ribbon-like area near the Caspian Sea with two wide } \\
\text { lands at central and western parts is a proper choice to host MICE activities in the region from } \\
\text { the viewpoint of P.L indexes. }\end{array}$ \\
\hline
\end{tabular}

\section{Introduction}

Today, development is a plan to respond the socio-economic expectations of the society and also to create a high quality of life for the residents (Ness, 2001). In other words, the purpose of developmental planning in each society is to increase the level of income, employment, education, health, food, and housing and also to eradicate poverty (Taghvaei \& Rahmati, 2006). On the other hand, the theoreticians discuss the necessity of accurate urban and regional planning in order to reach a balanced development. They believe that balanced development and facilities reduce the intraregional and inter-regional differences of life quality by producing the best conditions (Bhatia, 2004). Therefore, the conscious act of planning to achieve an urban and regional development includes decentralization, redistribution of benefits to reduce inequalities and promotion of environmental quality (Khakpour \& Bavanpouri, 2009).

\footnotetext{
* Corresponding author. Tel: +989123509871

E-mail addresses: n.tab358@yahoo.com (N. Tabrizi) 
In Iran like many developing countries, achieving development and solving the problems of urban and regional inequalities are two important objectives of the national planning. In this regard, tourism industry is an effective method to make a multilateral promotion of residents' welfare. This industry has been a fertile field for entrepreneurial business (Li, 2008) and also the benefits of rapid tourism growth, such as gross domestic product (GDP) growth, the accumulation of foreign exchanges, job creation, and infrastructure enhancement, are widely welcomed by governments (Sheng \& Tsui, 2009). During the last two decades, the tourism industry has been evolved and modernized, significantly.

The highly competitive environment of the industry has forced tourism firms to look for ways to enhance their competitive advantage (Zhang et al., 2009). Moreover, proper investment in this field is one of the important policies to achieve the objectives of development (Papeli \& Saghaei, 2007). MICE tourism is a significant element of urban tourism-with special visitors who gather to take part in conferences, business activities, exhibitions and seminars-accelerate urban and regional development (Rogerson, 2005). However, in Iran, with regard to the novelty of this industry and lack of necessary grounds, no specialized planning and independent investment have been organized in this field so far.

Throughout the country, all ministries, offices, institutes and organizations are working in parallel to create necessary facilities such as exhibition centers, meeting rooms, conference halls and other services to perform the MICE activities, so bear immense costs. These activities are not economically profitable in future and they will also face the problems of renovation and maintenance. Thus, selection of particular locations for the hosting of meetings, incentives, conventions and exhibitions tourism (MICE) events is beneficial and necessary. Based on the National Development plan of Iran, the northern region around the Caspian Sea is highlighted as one of the tourism poles because of its special features. Hence, as a most noticeable choice, it can play a professional role in hosting MICE tourism in Iran. Since hosting of MICE activities demand certain features, this research intends to study the capability of the northern part of Iran to host MICE events by perspective of physical and location related (PL) indexes and identify the proper areas from the standpoint of mentioned indexes.

\section{Theoretical background}

\subsection{The effect of MICE tourism on urban and regional development}

MICE tourism as a professional element in tourism industry is one of the effective methods in urban and regional development. The studies on MICE tourism in different countries show that the economic growth has occurred in all regions either with a low or an average income. However, in the low-income regions, development took place in infrastructures, facilities and education parts; whereas in the medium-income regions, the development occurred in the field of social development, health services and level of gross income (Pao, 2004).

Today, MICE tourism has been identified as one of the largest industries at global level and it brings rapid economic efficiency. According to the statistical reports, in 2008 MICE tourism produces 53 billion dollars profit in the world and at present, its median income is about 1.16 Trillion dollars per year. Studies show that generally, the benefits of this kind of tourism are transferred to the host community in three forms:

1. Direct benefit: Paying the direct economic costs to the MICE managers for utilizing their host services by the customers.

2. Secondary benefits: Including side costs of hotels, restaurants, using various attractive places, shopping, etc.

3. Non-economic benefits: Including the positive impacts of MICE visitors on cultural promotion, public education, local economy, indigenous values dissemination, etc. (Yi Wu et al., 2008). 
Note that the financial circulation of MICE tourism is more important than the direct income and these activities usually are valued for three effects; large opportunities for employment, beneficial innovations and efficient utilization of assets (Papeli \& Saghayee, 2007). On the other hand, MICE events are held naturally for different scientific, social, cultural and political objectives and also exchange of information and views (Movahed, 2007).

Studies show that MICE tourists hang around 2.4 times more in urban environments compared with recreational tourism visitors (Davidson, 2007). Since the indirect education is one of the effective methods to promote the socio-cultural levels of the society, preparing appropriate interaction between indigenous people and special visitors of MICE can play a great and undeniable role in the progress of society culture.

\subsection{Necessary traits to host MICE tourism}

Despite global development and the undeniable importance of MICE tourism, studies and researches on the topic are still insufficient and in contrast to other tourism branches, related principles and instructions are not developed yet. Therefore, each country schedules this field with regard to the knowledge of its own planners and its conditions (MGTO report, 2006).The general consensus is that MICE organizers take account of four key attributes when selecting MICE places:

- Quality of MICE facilities,

- Location and accessibility,

- Image of potential locations,

- Costs and expenditures (Rogerson, 2005).

The relative importance of these four factors will vary, however, according to the nature of particular conferences or exhibitions, the role of other factors such as climatic conditions, cultural features, population structure, etc are less important for MICE places.

\section{Material and methods}

\subsection{Identification of key P.L indexes for MICE hosting}

The most important physical and location related (P.L) indexes for MICE tourism hosting are the geographical position, location and the quality of its accessibility. Studies show that the successful cities in this area have enjoyed the following features from the viewpoint of P.L indexes,

1. Adequate location:

-Proximity to the international borders,

-Proximity to the capital city,

2. Proper distances between cities,

3. Being located at the main route of accessibility,

4. Enjoying diverse transportation networks including railroads, airlines, roads and sea routes.

In the most of developed tourism regions, a vast appropriate transportation network exists. The transportation network must provide a proper and efficient access from the national gates to the regional ones and finally to the cities with attractions and facilities (World Tourism Organization, 2009). Each transport system acts differently in time, number and duration of travels depending on its characteristics. However, more than one and may be all transportation networks are needed to be involved simultaneously in some cases (Qarahnejad, 2009). In this part, the mentioned features are studied in the north region of Iran: 


\subsubsection{Adequate location}

Previous studies and experiences show that the location of a region is one of the most important indexes in the hosting of MICE tourism. On one hand, traveling in the shortest possible time to participate in MICE events is an expected necessity of this industry, and on the other hand, the location of a region has an effective role in supplying its potentials and attractions. The north region of Iran is located at a temperate zone and in the neighborhood of the Caspian Sea. Thus, it enjoys diverse natural attractions and also access to the sea transportation. This region has international borders in two sides; the North West and the North East. It contacts to six province centers directly and depending on the selected mean of transport, this region is within 30 minutes to 3 hours driving distance of capital city

\subsubsection{Proper distances between cities}

The Transportation networks are established in order to procure access of different regions with each other. Distance is the most important factor for the access of cities to each other. Hence, shorter distance between cities causes stronger access among them. The great advantage of the northern cities of Iran is their attractions and proximity to natural environment. On the other hand, the proper distance between cities is a positive factor to organize secondary attractive plans for MICE tourism. In addition, it increases the chances of making partner cities for MICE services.

\subsubsection{Being located at the main route of accessibility}

The activities of different types of tourism especially MICE tourism, have direct or indirect correlations with the transportation networks. For many conventions, conferences and exhibitions, not only the characteristics of the event venue but also its location are significant. In particular, if the mentioned activities are held in a one-day or short-term period, the proper access to the transportation networks is of higher importance. The situation of transportation networks in the north region of Iran can be studied at international and regional levels:

\section{- International corridors nearby the region}

There are five international transport corridors in Iran where three of them are directly in connection with the north region. These routes facilitate the tourists transfer for participation in regional conventions and conferences. In addition, they accelerate the transportation of goods for other activities of MICE, like exhibitions. These routes include:

-North-South Transport Corridor (NOSTRAC)

NOSTRAC provides sea transportation between the Caspian Sea and the North Sea through Volga

River, and also facilitate transfer of goods and MICE visitors from neighboring countries and Northern Europe to the Caspian Sea.

-The Transport Corridor Europe Caucasus Asia (TRACECA)

Three neighboring countries of Iran at the margin of the Caspian Sea i.e. Azerbaijan, Kazakhstan and Turkmenistan have established a new shipping and sea transportation line through the Caspian Sea that has an undeniable role in different types of MICE activities.

-Asian Highway

At present, the length of the Asian highway network is over 140 thousands kilometers and traverses 32 member countries. The path of the mentioned highway in the north region is as follows:

AH7 route: It arrives from Incheh Borun border into Golestan province. Then, passing through the cities of Sari, Semnan, Yazd and Anar and leads to Bandar Abas. 


\section{-Intra-transportation networks of the region}

The Intra-transportation network of the northern region is located at the main country transport axis, particularly from the viewpoint of road transport system.

\subsubsection{Diverse transportation networks}

One of the most appropriate methods of transportation system analysis is measurement based on transport means and locations. The transportation activities in the north region can be considered in four groups:

\section{- Road transportation}

The road networks of the region have unique features compared with other parts of the country, which make them to serve as a linking bridge between the North West and the North East. The contributing features are as below,

-The linear form of the region,

-Low width to length proportion,

-Longitudinal establishment of urban areas in the region,

-The linear form of transportation networks in proportion to shape of the region.

On the other hand, the main routes, which cover the region width start from the gate cities of the region and link to six province centers and also the capital city. Statistics also show that the density of main roads in each 100 square kilometers of the region is approximately 3.5 times as many as the national average. Thus, the road networks of the region provide proper access for tourists and applicants of MICE.

\section{- Rail Transportation}

The importance of rail transportation in the MICE activities is obvious. The high safety, low energy consumption, low environmental pollution, insignificant impacts of atmospheric condition on this system are its most important advantages compared with other transportation systems of the region. In the eastern part of the region, the rail network begins from Gorgan in Golestan province, passing several cities and finally connects to Tehran.

\section{- Air transportation}

Air transportation system is one of the most suitable methods of long distance transfer. The high speed, regular schedules, services and relative comfort of passengers are the main advantages of this system. At present, five airports are working in the region. Considering the balanced distribution of airports and the short distances between intra-regional cities, it seems that the air transportation will have a considerable effect on proper access of tourists to their destinations. Furthermore, it will also influence the thriving state of MICE tourism in the region.

\section{- Sea transportation}

The sea transportation system of the northern region has a specific position. The Caspian Sea with an area of about 438000 square kilometers is identified as the largest lake on the earth. It connects the north region of Iran to the northern and southern ports of the Europe through Volga River, the Black Sea and Baltic Sea. In addition, by the means of Caspian Sea, linking to the neighboring countries through Baku in Azerbaijan, Makhach Qala and Astarakhan in Russia, Aktau in Kazakhstan and 
Turkmanbashi in Turkmenistan is possible. Presently six ports are active at the region, and full access to sea transportation network will be possible for more than forty cities in the near future.

\subsection{Methodology}

\subsubsection{Fuzzy logic}

Fuzzy logic began with the 1965 proposal of fuzzy set theory by Zadeh (1968) and the Fuzzy logic has been applied to many fields, from control theory to artificial intelligence. Fuzzy logic is a form of many-valued logic; it deals with reasoning that is approximate rather than fixed and exact. In contrast with traditional logic theory, where binary sets have two-valued logic: true or false, fuzzy logic variables may have a truth values, which ranges in degree from 0 to 1 . Fuzzy logic has been extended to handle the concept of partial truth, where the truth value may range between completely true and completely false. Furthermore, when linguistic variables are used, these degrees may be managed by specific functions.

The fuzzy logic is a powerful concept to solve the problems related to complicated systems or the problems, which are dependent on reasoning, decision making and inference. The fuzzy principle states that everything is relative. Fuzzy, means containing multiple values and represents that in response to every question, there are three choices or more. Perhaps, there might be an infinite spectrum of choices instead of only two final choices.

In this research, in order to match the respective indexes, the fuzzy logic has been used. The most important stage in fuzzy matching is selection of a membership function. Based on the fuzzy absolute theory, the membership functions can be studied in two categories of continuous and disrupted (Fakhudi, 2005). In matching the used indexes, mainly linear membership function has been used.

\subsubsection{Fuzzy Linear}

The fuzzy linear transformation function applies a linear function between the user-specified minimum and maximum values. Anything below the minimum will be assigned a 0 (definitely not a member) and anything above the maximum a 1 (definitely a member). The blue line in the image below represents a positive sloped linear transformation with a minimum of 30 and a maximum of 80 . Any value below 30 will be assigned a zero and anything above 80 a 1 . If the minimum is greater than the maximum, a negative linear relationship (a negative slope) is established. The red line in the image below represents a negative slope linear transformation. Any value less than 30 will be assigned 1 and anything above 80 will be given zero. The slope of the line is increasing or decreasing defines the transition zone, between 30 to 80 in the image shown in Fig. 1. In other words, the Fuzzy linear membership function transforms the input values linearly on the 0 to 1 scale, with 0 being assigned to the lowest input value and 1 to the largest input value. All the in-between values receive some membership value based on a linear scale, with the larger input values being assigned a greater possibility, or closer to 1 . Therefore, we have,

$$
\mu_{i}(x)=\left\{\begin{array}{lll}
1 & \text { If } & x<D_{i} \\
\frac{x_{M A X}-x}{\Delta x} & \text { If } & D_{i} \leq x<D_{i}^{\prime} \\
0 & \text { If } & x \geq D_{i}^{\prime}
\end{array}\right.
$$




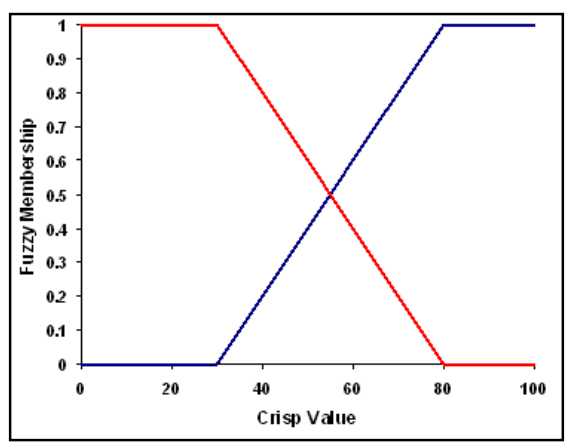

Fig. 1. Graph of fuzzy linear transformation function

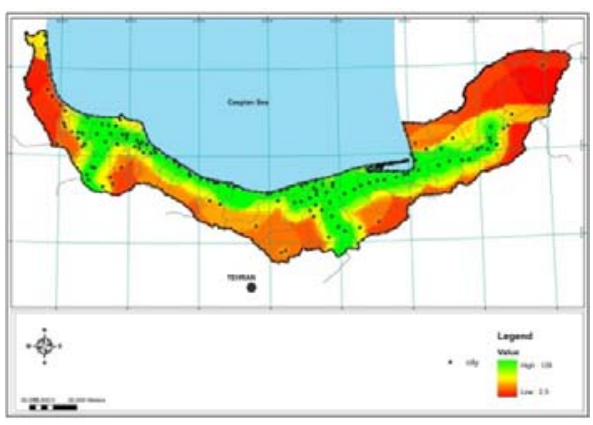

Fig. 2. Suitable areas for MICE hosting from the viewpoint of PL indexes in the North Region of Iran

\section{Results}

At this stage, the P.L indexes were transformed to Raster data layers and these layers were converted into fuzzy layers based on linear membership function. Because of GIS ability to analyze descriptive and spatial data separately or simultaneously, in this part of study, the ArcGIS was used as the software of database management and also spatial analyst and IDRISI software were utilized concurrently for analysis and overlaying of different data layers. The results are demonstrated in Table 1. Using this method, the entire region was quantified by scores and finally, the map of suitable areas for MICE hosting were produced from the viewpoint of PL indexes (Fig. 2).

\section{Table 1}

Degree of membership and Fuzzy value of P.L Indexes based on linear membership function

\begin{tabular}{|c|c|c|}
\hline Indexes & Degree of Membership & Fuzzy Value \\
\hline \multirow{5}{*}{$\begin{array}{l}\text { Proper distances between cities } \\
\text { SD }=2455\end{array}$} & $x<659$ & 1 \\
\hline & $659 \leq x<3114$ & \multirow[b]{2}{*}{$\underline{x_{M A X}-X}$} \\
\hline & $3114 \leq x<5568$ & \\
\hline & $5568 \leq x<8023$ & $\Delta x$ \\
\hline & $x \geq 8023$ & 0 \\
\hline \multirow{4}{*}{$\begin{array}{l}\text { Proximity to the international borders } \\
\mathrm{SD}=79.3\end{array}$} & $x<3.9$ & 1 \\
\hline & $3.9 \leq x<83.2$ & $x_{M A X}-x$ \\
\hline & $83.2 \leq x<241.8$ & $\Delta x$ \\
\hline & $x \geq 241.8$ & 0 \\
\hline \multirow{4}{*}{$\begin{array}{l}\text { Being Located at the main route of } \\
\text { accessibility } \\
S D=27.7\end{array}$} & $x<17.3$ & 1 \\
\hline & $17.3 \leq x<45.1$ & $x_{M A X}-x$ \\
\hline & $45.1 \leq x<72.9$ & $\Delta x$ \\
\hline & $x \geq 72.9$ & 0 \\
\hline \multirow{5}{*}{$\begin{array}{l}\text { Proximity to the capital city } \\
S D=118.4\end{array}$} & $x<63.9$ & \multirow{3}{*}{$\underline{X_{M A X}-X}$} \\
\hline & $63.9 \leq x<182.4$ & \\
\hline & $182.4 \leq x<300.7$ & \\
\hline & $300.7 \leq x<419.1$ & $\Delta x$ \\
\hline & $x \geq 419.1$ & 0 \\
\hline \multirow{4}{*}{$\begin{array}{l}\text { Enjoying diverse transportation networks } \\
\mathrm{SD}=57.7\end{array}$} & $x<49.2$ & 1 \\
\hline & $49.2 \leq x<106.9$ & $x_{M A X}-x$ \\
\hline & $106.9 \leq x<164.7$ & $\Delta x$ \\
\hline & $x \geq 164.7$ & 0 \\
\hline
\end{tabular}




\section{Conclusion}

Today, Professional activities in the field of MICE hosting is one of effective approaches to urban and regional development and bring different benefits to the host community. This hosting requires social, economic, physical and cultural features and services. Global experiences show that there are several indexes are of specific importance for the host community such as proximity to the international borders or capital city, proper distances between cities, etc. The study of mentioned indexes in the northern region of Iran by using fuzzy logic and the geographical data system showed that the ribbon-like area near the Caspian Sea with two wide lands at central and western parts is a proper choice to host MICE activities in the region from the viewpoint of PL indexes.

\section{References}

Bhatia, V.K., \& Rai, S.C. (2004). Evaluation of socio - economic development in small areas. New Dahlia.

Davidson, L. (2007). 10 $0^{T H}$ Tourism Congress, University and Company Convention, Congress and Incentive travel. Valencia, 15-35.

Department of Geographical Studies. (2009). A regional plan for Guilan and Mazandaran (Geographical and environmental studies).Tehran: Ministry of Housing and Urban Development Publishing.

Fakhudi, A. (2005). Using fuzzy logic in planning and regional development. Science and Development Journal, 17, 39- 61.

Jantzen, J. (1998). Tutorial on fuzzy logic. Technical university of Denmark, Department of Automation, report No. 98-E 868.

Khakpour, B., \& Bavanpouri, A. (2009). Analysis of inequality at the levels of districts development in Mashhad city. Journal of Knowledge and Development, 37, 182-202.

Li, L. (2008). A review of entrepreneurship research published in the hospitality and tourism management journals. Tourism Management journal, 29, 1013-1022.

Movahed, A. (2007).Urban Tourism. Ahvaz: Chamran University Publishing.

Ness, P. (2001). Urban planning and sustainable development. European Planning Studies, 4, 135147.

Pao, J.W. (2004). Recent Developments and Prospects of Macao's Tourism Industry. Monetary Authority of Macao, 79-95.

Papeli, M.H., \& Saghaie, M. (2007). Tourism, Nature and Concepts. Tehran: SAMT Publications.

Qarahnejad, H. (2009). Tourism Industry and Its Economic Analyses. Najafabad: Publications of Najafabad University.

Rogerson, C.M. (2005). Conference and Exhibition Tourism in the Developing World: The South African Experience. Urban Forum Journal, 2, 176-195.

SAP Consulting Engineers. (2006). A project for the development of tourism industry in the coastal area of Caspian Sea.

Sheng, L., \& Tsui, Y. (2009). A general equilibrium approach to tourism and welfare: The case of Macao. Habitat International Journal, 33, 419-424.

Statistical Center of Iran. (2006). Statistical Yearbook of National Transportation. Tehran: Planning and Strategic Supervision, Office Publishing.

Taghvaei, M., \& Rahmati, S. (2006). Analysis of culture indexes in provinces of Iran. Geography Regional Development Journal, 17, 117-132.

World Tourism Organization. (2009). National and Regional Planning for Tourism. Tehran: Cultural Researches Office Publishers.

Yi Wu, P., Auld, C.\& Lloyd, K. (2008). The Factors Influencing Corporate Social Responsibility Behavior in the MICE Industry. CAUTHE 2008 Conference, 1-8.

Zadeh, L.A. (1968). Fuzzy algorithms, Information. \& Culture. , 12, 94-102.

Zhang, X., Song, H.\& Huang, G., (2009).Tourism supply chain management: A new research agenda. Tourism Management Journal, 30, 345-358. 